\title{
Strategi Guru Pendidikan Agama Islam dalam Mengembangkan Sikap Spiritual Siswa Kelas VII SMP Negeri 6 Palembang
}

\author{
Inne Aprinda ${ }^{1 *}$, Amilda $^{2}$, Mardiah Astuti $^{3}$ \\ ${ }^{1 *}$ SMP Negeri 6, Palembang, Indonesia \\ inneazza4@gmail.com \\ ${ }^{2}$ Universitas Islam Negeri Raden Fatah, Palembang, Indonesia \\ amilda uin@radefatah.ac.id \\ ${ }^{3}$ Universitas Islam Negeri Raden Fatah, Palembang, Indonesia \\ mardiahastuti_uin@radenfatah.ac.id
}

\begin{abstract}
The research aims to describe and analyze the PAI teacher's strategy in developing the spiritual attitude of Grade VII students of SMPN 6, and the factors that influence the PAI teacher's strategy in developing the spiritual attitude of VII students of SMPN 6 Palembang. The results of the study show that, (1) develop the spiritual attitude of VII grade students of SMP Negeri 6 Palembang, namely through the habit of praying after the Oth hour, habituation of the Duha and Dhuhr prayer in congregation, then through teacher guidance to students by giving advice or motivation, by teacher modeling, and approaching through methods exemplary story (2) Factors supporting the PAI teacher's strategy in developing the spiritual attitude of VII grade students of SMP Negeri 6 Palembang are the existence of creative teachers, the hard work of teachers in motivating students to have good morals, the existence of school programs that support the development of spiritual attitudes of students, the existence of work the same is good between the principal d ith the teacher in the school, the existence of an adequate mosque to carry out worship, the collaboration between parents of students and teachers. While the inhibiting factors are lack of awareness and motivation in students, and lack of supervision from parents in matters of worship.
\end{abstract}

Keywords : PAI Teacher Strategy, Spiritual Attitude.

\section{INFORMASI ARTIKEL}

Submitted, April 12, 2020

Revised, Mei 09, 2020

Accepted, June 26, 2020 


\section{PENDAHULUAN}

Pendidikan agama Islam sebagai salah satu mata pelajaran yang mengandung muatan ajaran-ajaran Islam dan tatanan nilai hidup dan kehidupan islami dipandang perlu diarahkan agar guru dapat membekali siswa dengan pengetahuan, pemahaman, penghayatan, dan pengamalan ajaran Islam. Dalam hal ini pembelajaran PAI harus menempatkan ajaran Islam sebagai suatu objek kajian yang melihat Islam sebagai sebuah sistem nilai dan sistem moral yang tidak hanya diketahui dan dipahami, tetapi juga diwujudkan dalam perilaku keseharian di masyarakat. Kegagalan Pendidikan Agama Islam disebabkan pembelajaran PAI lebih menitikberatkan pada hal-hal yang bersifat formal dan hafalan, bukan pada pemaknaannya (Majid \& Andayani, 2005). Sehingga hal ini yang membuat siswa, mahir pada ranah kognitif saja dan kurang mahir pada ranah afektif. Hal ini dapat demikian juga dalam upaya meningkatkan mutu pendidikan, PAI harus dijadikan tolak ukur dalam membentuk watak dan pribadi peserta didik, serta membangun moral bangsa (Alim, 2006).

Pendidikan Agama Islam berkaitan erat dengan ranah afektif karena berorientasi pada perilaku siswa sehari-hari sebagai pengamalan nilai-nilai agama. Aspek afektif inilah yang menjadi perhatian khusus dalam Pendidikan Agama Islam. Aspek afektif yang terkandung di dalam Pendidikan Agama Islam meliputi sopan santun siswa terhadap guru, kepada orang tua, keluarga, teman dan orang yang lebih tua baik di lingkungan sekolah, rumah, ataupun masyarakat. Ranah afektif adalah ranah yang berkaitan dengan sikap dan nilai (Sudijono, 2005). Sikap merupakan hubungan dari persepsi dan tingkah laku di dalam istilah suatu bidang psikologi. Istilah sikap dalam bahasa Inggris disebut attitude. Attitude adalah suatu cara bereaksi terhadap suatu perangsang atau situasi yang dihadapi. Sikap melibatkan beberapa pengetahuan tentang situasi, namun aspek yang paling esensial dalam sikap adalah adanya perasaan atau emosi, kecenderungan terhadap perbuatan yang berhubungan dengan pengetahuan (Sudjana, 2005).

Ranah afektif merupakan kemampuan yang mengutamakan perasaan, emosi, dan reaksireaksi yang berbeda dengan penalaran (Dimyati \& Mudjiono, 2006). Kawasan afektif yaitu kawasan yang berkaitan aspek-aspek emosional, seperti perasaan, minat, sikap, kepatuhan terhadap moral dan sebagainya. Ranah afektif terdiri dari lima ranah yang berhubungan dengan respons emosional terhadap tugas. Yaitu respon, memperhatikan, menanggapi, menghargai, mengatur dan karakterisasi. Menurut Anas Sudijono, ciri-ciri hasil belajar pada ranah afektif akan tampak pada peserta didik dalam berbagai tingkah laku. Hal itu dapat ditaksonomi lebih rinci menjadi lima jenjang, yaitu receiving (menerima atau memperhatikan), responding (menanggapi), valuing (menilai atau menghargai), organization (mengatur atau mengorganisasikan) dan characterization (karakterisasi dengan suatu nilai atau komplek nilai).

Dalam kurikulum 2013, ranah sikap tercakup pada rumusan kompetensi inti (KI). Kurikulum 2013 membagi kompetensi sikap menjadi dua, yaitu sikap spiritual dan sikap sosial (Wazdy \& Suyitman, 2014). Sikap spiritual sebagai perwujudan dari menguatnya interaksi vertikal dengan Tuhan Yang Maha Esa, sedangkan sikap sosial sebagai perwujudan eksistensi kesadaran dalam upaya mewujudkan harmoni kehidupan. Kurikulum 2013 membagi kompetensi sikap menjadi dua, yaitu sikap spiritual dan sikap sosial. Sikap spiritual sebagai perwujudan dari menguatnya interaksi vertikal dengan Tuhan Yang Maha Esa, sedangkan sikap sosial sebagai perwujudan eksistensi kesadaran dalam upaya mewujudkan harmoni kehidupan (Wazdy \& Suyitman, 2014). Salah satu aspek implementasi kurikulum 2013 yang menarik dan penting diteliti adalah pengembangan sikap spiritual siswa. Sebab menjadi ciri khas kurikulum 2013, pengembangan sikap spiritual siswa oleh guru tidak boleh dilakukan dengan cara mengajarkan sikap secara langsung kepada siswa di kelas. Hal ini menuntut guru harus kreatif dalam mengembangkan sikap spiritual siswa melalui pemilihan media atau metode pembelajaran yang tepat, dan strategi pembelajaran yang sesuai. Oleh karena itu, diperlukan 
strategi pembelajaran yang pas dan cocok sesuai dengan gaya belajar siswa, sehingga dapat menghasilkan siswa yang aktif dalam pembelajaran terutama pada sikap spiritual.

\section{METODOLOGI}

Jenis penelitian ini menggunakan penelitian deskripstif kualitatif. Dalam pendekatan deskriptif, data yang dikumpulkan adalah berupa kata-kata, gambar, dan bukan angka-angka. Penelitian ini bertujuan untuk mendapatkan data/gambaran yang objektif, faktual, akurat dan sistematis, mengenai masalah yang akan dikaji oleh peneliti. Analisis data dilakukan dengan menganalisis selama dilapangan terhadap data yang berhasil dikumpulkan dan dari makna itulah ditarik kesimpulan. Untuk memperoleh data tentang masalah yang akan di teliti, maka peneliti menggunakan beberapa metode antara lain: 1) Metode Observasi, pelaksanaan observasi dilakukan dengan cara pengamatan secara langsung (non partisipan). Aspek yang diamati dalam peneliti ini adalah: lokasi sekolah, lingkungan sekolah, ruang kelas, sarana dan prasarana belajar mengajar, proses belajar mengajar di kelas, strategi dan metode pembelajaran, kegiatan keagamaan di sekolah, observasi sikap dan perilaku siswa ketika mengikuti kegiatankegiatan keagamaan rangka pengembangan sikap spiritual. 2) Metode interview (wawancara).

Dalam penelitian ini peneliti menggunakan teknik wawancara terstruktur dan semi terstruktur. Dengan terstruktur dapat dipersiapkan sedemikian rupa pertanyaan-pertanyaan. Wawancara ini ditujukan kepada Kepala Sekolah, guru PAI kelas VII, siswa SMPN 6 Palembang. Dari informan-informan, peneliti mendapatkan data ataupun informasi yang lebih mendalam tentang strategi guru pendidikan agama Islam, faktor pendukung dan penghambat strategi guru dalam mengembangkan sikap spiritual siswa kelas VII SMP Negeri 6 Palembang. 3) Metode Dokumentasi. Dokumen dalam penelitian ini diantaranya: gambar kegiatan proses belajar mengajar Pendidikan Agama Islam di dalam kelas dan diluar kelas, struktur organisasi, SK sekolah bermutu, kegiatan jam ke - 0 .

\section{HASIL DAN PEMBAHASAN}

Suatu pendidikan diperlukan suatu perhitungan situasi dan kondisi dimana ditentukan dalam jangka waktu yang panjang. Dengan perhitungan tersebut maka akan proses pembelajaran akan lebih terarah lebih matang. Oleh karena itu, pendidikan memerlukan strategi dalam prosesnya sehingga pendidikan dapat berjalan dengan baik dengan melihat situasi dan kondisi yang ada (Arifin, 1996). Hal ini mengindikasikan bahwa peran strategi agar mencapai tujuan yang telah ditentukan sangatlah penting. Oleh sebab itu, sebelum menentukan strategi, perlu dirumuskan tujuan yang jelas yang dapat diukur keberhasilannya sebab tujuan adalah rohnya dalam implementasi suatu strategi. yang mana tujuan pembelajaran PAI sendiri yaitu untuk menjadikan peserta didik agar menjadi manusia yang beriman dan bertakwa, dan menjadi muslim yang berakhlak mulia, taat beribadah, dan mengamalkan ajaran-ajaran Islam.

Sebelum menggunakan strategi, guru menentukan terlebih dahulu indikator sikap spiritual sehingga dapat menentukan strategi yang tepat untuk digunakan dalam pembelajaran. Adapun indikator sikap spiritual pada penelitian ini meliputi: (berdoa sebelum dan sesudah melakukan sesuatu, menjalankan ibadah tepat waktu, bersyukur atas nikmat dan karunia Tuhan Yang Maha Esa, memelihara hubungan baik dengan sesama umat ciptaan Tuhan Yang Maha Esa). Salah satu strategi guru PAI yaitu melalui pembiasaan berdoa' setelah jam ke-0. Pembiasaaan berdoa dilakukan untuk mengembangkan indikator sikap spiritual berdoa sebelum dan sesudah melakukan sesuatu. Pada penelitian ini peneliti mengamati secara langsung strategi guru PAI melalui pembiasaan di kelas dan di luar kelas. Pembiasaan ini dilakukan supaya siswa semakin dekat dengan sang Pencipta dan supaya dalam melaksanakan setiap kegiatan menjadi lebih tenang. 
Kemudian strategi berikutnya yaitu melalui pembiasaan pelaksanaan sholat dhuha dan zhuhur berjama'ah. Hal ini dilakukan sebagai strategi guru pai untuk mengembangkan sikap spiritual menjalankan ibadah tepat waktu. Pembiasaan Pelaksanaan Sholat Dhuha di SMPN 6 dilaksanakan setiap pagi pada jam pertama yaitu pukul 07.00 WIB. Namun, ada juga sebagian siswa yang melakukannya pada jam istirahat pukul 09.40 WIB, hal ini dilakukan atas kamauan dan kesadaran siswa sendiri tanpa ada paksaan dari guru. Shalat Dhuha dilaksanakan sebanyak empat rakaat dan dipimpin oleh salah satu siswa yang telah ditunjuk oleh guru. Guru jam pertama ikut melaksanakan sholat dhuha, supaya dapat mengawasi siswa dalam pelaksanaan shalat dhuha, apabila ada siswa yang tidak serius dalam shalat maka akan dihukum untuk shalat sendirian dengan didampingi oleh guru.

Sementara Shalat Zhuhur secara berjama'ah dilaksanakan pukul $12.00 \mathrm{WIB}$, yaitu pada jam pelajaran ke -7. Imam shalat zhuhur dari pihak guru, namun jika berhalangan maka dapat digantikan oleh siswa. Strategi penerapan shalat dhuha dan shalat dhuhur berjamah ini dilakukan supaya siswa membiasakan diri untuk selalu mengingat Allah swt dimanapun dan kapan pun serta dari shalat berjamaah dapat diambil hikmah bahwa kita sebagai manusia haruslah hidup rukun. Shalat memiliki pengaruh yang efektif dalam menyembuhkan manusia dari duka cita dan gelisah. sikap berdiri pada waktu shalat di hadapan Tuhannya dalam keadaan khusyu', berserah diri dan pengosongan diri dari kesibukan dan permasalahan hidup dapat menimbulkan perasaan tenang, damai dalam jiwa manusia, serta dapat mengatasi rasa gelisah dan ketegangan yang ditimbulkan oleh tekanan-tekanan jiwa atau masalah kehidupan. Seperti diriwayatkan Hudzaifah, bahwa beliau Rasulullah saw selalu shalat ketika menghadapi kesulitan. Hal ini menjadikan shalat memiliki pengaruh tetapi dalam menghadapi stress dan rasa gelisah. shalat sebagai hubungan manusia dengan Tuhannya, memberikan energi ruhani dan juga dapat menyembuhkan penyakit fisik. Energi ruhani shalat juga dapat membantu membangkitkan harapan, menguatkan tekad, meninggikan cita-cita dan juga melepaskan kemampuan-kemampuan luar biasa yang juga bisa menjadikan lebih siap dalam menerima ilmu pengetahuan dan hikmah (Rahayu, 2009).

Strategi berikutnya yaitu melalui pemberian motivasi dan bimbingan guru. Dalam penelitian ini, guru sebagai pendorong dari luar diri siswa. Guru memberikan motivasi kepada siswa pada saat pembelajaran berlangsung. Yakni pada kegiatan pendahuluan, inti dan juga penutup. Guru selalu memberi penekanan kepada siswa untuk bersikap jujur, taat beribadah, sabar dan syukur. Dengan memberikan stimulus, maka siswa mampu merangsang kegiatan pembelajaran dengan baik. Pemberian motivasi kepada siswa sangat berarti untuk memulai pembelajaran agar siswa lebih bersemangat mengikuti pembelajaran. Salah satunya memberikan stimulus dan dihubungkan dengan kehidupan sehari-hari. Selain itu, dengan membiasakan siswa untuk selalu mengucapkan terima kasih setiap kali mendapat kebaikan dari temannya, dengan tidak memandang kebaikan yang diperoleh itu sedikit atau banyak. Hal ini juga termasuk mengucapkan alhamdulillah setiap kali memperoleh kebaikan yang diberikan oleh Tuhan, termasuk kemudahan dan kehidupan yang diberikan-Nya.

Kemudian strategi berikutnya yaitu melalui keteladan guru. Seperti, menjalin hubungan serta komunikasi yang baik dengan siswa, dan guru lainnya. Kemudian guru memberikan tanggapan dengan pujian dan tepuk tangan kepada siswa yang dapat menjawab pertanyaan dari guru dan siswa yang lainnya. Namun, Jika ada siswa yang salah menjawab pertanyaan guru tidak mematahkan semangat siswa untuk menjawab, melainkan guru memberikan motivasi dan penguatan untuk mencari jawaban yang lebih tepat. Kemudian dengan pendekatan dan nasihat melalui kisah teladan rasul-rasul yang hidup di zaman jahiliyah, dimana terdapat hikmah atau pelajaran dari kisah tersebut. Konsep keteladanan ini sudah diberikan dengan cara Allah mengutus Nabi SAW untuk menjadi panutan yang baik bagi umat Islam sepanjang sejarah dan bagi smeua manusia di setiap masa dan tempat. Keteladanan ini harus senantiasa di pupuk 
dipelihara dan dijaga oleh para pengemban risalah. Guru harus memiliki sifat tertentu sebab guru ibarat naskah asli yang hendak difotokopi. Guru dengan bertutur kata yang baik dengan pemilihan bahasa yang baku dan mudah dipahami oleh siswa. Karena siswa cenderung meniru apa yang dikatakan oleh guru, siswa hafal dengan kata yang diucapkan oleh guru. Misalnya guru selalu mengucapkan alhamdulillah ketika masuk kelas, dan membaca bismillah akan mulai belajar serta mengucapkan astagfirllahalazhim kalau lupa, dan menjatuhkan sesuatu. Guru bersikap ramah dan peduli, misalnya ketika bertemu siswa, guru senyum, sapa dan salam, Maka dari itu, siswapun akan meniru perilaku guru. Teguran atau memberikan nasehat juga guru terapkan selama proses pembelajaran.

Kemudian pendekatan melalui metode kisah. Metode ini merupakan metode yang digunakan guru pada saat proses pembelajaran untuk mengembangkan indikator sikap spiritual: menghormati orang lain menjalankan ibadah sesuai dengan agamanya. Bercerita atau berkisah, metode ini disampaikan dengan bercerita/berkisah tentang kisah-kisah agung, kisah dari orangorang dalam sejarah yang mempunyai kecerdasan spiritual yang tinggi. Metode ini dinilai sangat efektif karena anak sangat menyukai cerita (Azzet, 2010). Selain itu, bercerita tentang Rasul sebagai suri tauladan dalam adab berhubungan dengan orang lain untuk menambah pengetahuan siswa dan membuat pelajaran di dalam kelas tidak menjenuhkan serta agar siswa dapat menjaga hubungan yang baik dengan guru dan sesama temannya serta dapat menghormati orang lain menjalankan ajaran agama yang dianutnya.

Dalam setiap proses pelaksanaan sebuah pengembangan pendidikan tidak selalu berlangsung lancar. Namun, ada beberapa faktor-faktor yang menghambat dan mendukung manakala pengembangan itu dilakukan. Salah satu faktor pendukung dalam mengembangkan sikap spiritual siswa yaitu adanya pengalaman, ilmu pengetahuan serta mental guru dalam mengajar. Kemudain adanya kerjasama yang baik antara guru PAI dengan guru mata pelajaran umum. Pengembangan sikap spiritual itu sudah didukung oleh perintah yang ada dalam Undang-Undang yang tercantum pada tujuan pendidikan itu sendiri. Bahwa mengembangkan potensi siswa agar menjadi manusia yang beriman dan bertakwa kepada Tuhan Yang Maha Esa. Sekolah juga mendukung melalui visi dan misi sekolah yaitu terwujudnya siswa yang berakhlak mulia, berprestasi, berwawasan lingkungan dan global. Ada beberapa faktor pendukung dalam mengembangkan sikap spiritual siswa diantaranya: Tersedianya guru yang kreatif, hal ini terlihat dari cara guru dalam menyampaikan materi pelajaran.

Kreatifitas guru merupakan faktor penting yang besar pengaruhnya, bahkan sangat menentukan berhasil-tidaknya peserta didik dalam belajar. Pembelajaran harus sebanyak mungkin melibatkan peserta didik, agar mereka mampu berekplorasi untuk membentuk kompetensi dengan menggali berbagai potensi, dan kebenaran secara ilmiah. Dalam kerangka inilah perlunya kreativitas guru, agar mereka menjadi fasilitator, dan mitra belajar bagi peserta didik. Hal ini terlihat dari kerja keras guru dalam memotivasi siswa, pemilihan metode oleh guru yang bervariatif, Guru menguasai materi pembelajaran. Kemudian Adanya sifat teladan guru yang dicontohkan kepada siswa, adanya program sekolah yang mendukung segala aktifitas kegiatan dalam pengembangan sikap spiritual. Salah satunya Ektrakurikuler BTA, adanya kerja sama yang baik antara kepala sekolah dengan guru yang ada di sekolah ini.

Adanya sarana prasarana yang memadai untuk mengembangkan sikap spiritual siswa, salah satunya, ada musholla untuk melaksanakan ibadah sholat zhuhur dan dhuha, tersedianya media pembelajaran yang memadai sehingga memungkinkan pembelajaran berlangsung dengan lancar. Manfaat media pengajaran dalam proses belajar siswa antara lain: Pengajaran akan lebih menarik perhatian siswa sehingga dapat menumbuhkan motivasi belajar, bahan pengajaran akan lebih jelas maknanya sehingga dapat lebih dipahami oleh para siswa, dan memungkinkan siswa menguasai tujuan pengajaran lebih baik, Penggunaan media pengajaran 
dalam proses pengajaran sangat dianjurkan untuk mempertinggi kualitas pengajaranserta adanya kerja sama antara orang tua siswa dan guru.

Faktor penghambat strategi guru dalam mengembangkan sikap spiritual siswa kelas VII di SMP Negeri 6 diantaranya kurangnya kesadaran dan motivasi dalam diri siswa untuk menjalankan ibadah tepat waktu dan mendengarkan arahan guru, dan lingkungan keluarga. yaitu siswa yang berasal dari background keluarga yang berbeda-beda. Ada yang berasal dari kalangan keluarga yang agama Islamnya sudah baik dan ada yang berasal dari keluarga yang Agama Islamnya belum baik. Hal ini membuat kurangnya pengawasan dari orang tua dalam hal ibadah. Setiap hambatan pasti terdapat solusi untuk mengatasinya. Solusi dalam mengatasi hambatan tersebut disampaikan oleh salah satu guru Pendidikan Agama Islam sebagai berikut: Solusinya untuk faktor yang menghambat tersebut ialah guru Pendidikan Agama Islam khususnya, yaitu dengan melakukan pendekatan individu kepada peserta didik. Jadi pemberian motivasi sampaikan sesuai dengan kebutuhan siswa dan tepat. Untuk solusinya dalam memberikan motivasi yaitu dengan didekati secara personal, dengan demikian siswa dapat melaksanakan kegiatan dengan tertib dan dapat mengikuti pelajaran apapun dengan baik.

\section{KESIMPULAN}

Strategi guru Pendidikan Agama Islam dalam mengembangkan sikap spiritual siswa kelas VII SMP Negeri 6 Palembang, yaitu melalui pembiasaan berdoa setelah jam ke -0, pembiasaan pelaksanaan shalat Dhuha dan Zhuhur berjama'ah, dengan pemberian motivasi dan bimbingan guru, keteladanan guru dan pendekatan melalui metode kisah. Adapun faktor pendukung strategi guru Pendidikan Agama Islam dalam mengembangkan sikap spiritual siswa kelas VII SMP Negeri 6 Palembang adalah adanya guru yang kreatif, adanya sifat teladan guru yang dicontohkan kepada siswa, adanya program sekolah yang mendukung pengembangan sikap spiritual siswa, adanya kerja sama yang baik antara kepala sekolah dengan guru yang ada di sekolah, adanya sarana prasarana yang memadai untuk mengembangkan sikap spiritual siswa, salah satunya ada musholla untuk melaksanakan ibadah, tersedianya media pembelajaran yang memadai sehingga memungkinkan pembelajaran berlangsung dengan lancar, adanya kerja sama antara orang tua siswa dan guru. Selain itu adapula faktor penghambatnya yaitu kurangnya kesadaran dan motivasi dari dalam diri siswa, dan kurangnya pengawasan orang tua dalam hal ibadah.

\section{DAFTAR PUSTAKA}

Alim, M. (2006). Pendidikan Agama Islam; Upaya Pembentukan Pemikiran Dan Kepribadian Muslim. Remaja Rosdakarya.

Arifin, H. M. (1996). Ilmu Pendidikan Islam. Bumi Aksara.

Azzet, A. M. (2010). Mengembangkan Kecerdasan Spiritual Bagi Anak. Kata Hati.

Dimyati, \& Mudjiono. (2006). Belajar dan Pembelajaran. Rineka Cipta.

Majid, A., \& Andayani, D. (2005). Pendidikan Agama Islam Berbasis Kompetensi (Konsep dan Implementasi Kurikulum 2004). PT. Remaja Rosdakarya.

Rahayu, T. I. (2009). Psikoterapi Prespektif Islam \& Psikologi Kontemporer. UIN-Malang Press.

Sudijono, A. (2005). Pengantar Evaluasi Pendidikan. PT. Raja Grafindo Persada.

Sudjana, N. (2005). Dasar-dasar Proses Belajar Mengajar. Sinar Baru Algensido.

Wazdy, S., \& Suyitman. (2014). Memahami Kurikulum 2013: Panduan Praktis untuk Guru Pendidikan Agama Islam dan Budi Pekerti. IAINU Kebumen. 